\title{
Validation and Psychometric Properties of the Portuguese Version of the Coronavirus Anxiety Scale (CAS) and Fear of COVID-19 Scale (FCV-19S) and Associations with Travel, Tourism and Hospitality
}

\author{
José Magano ${ }^{1,2, *(\mathbb{D})}$, Diogo Guedes Vidal ${ }^{3} \mathbb{D}$, Hélder Fernando Pedrosa e Sousa ${ }^{4}(\mathbb{D}$, \\ Maria Alzira Pimenta Dinis ${ }^{3, *}$ a and Ângela Leite ${ }^{5}$ (D)
}

1 ISCET-Higher Institute of Business Sciences and Tourism, Rua de Cedofeita, 285, 4050-180 Porto, Portugal

2 Research Center in Business and Economics (CICEE), Universidade Autónoma de Lisboa, Rua Sta. Marta 47, 5. Andar, 1150-293 Lisboa, Portugal

3 UFP Energy, Environment and Health Research Unit (FP-ENAS), University Fernando Pessoa (UFP), Praça 9 de Abril 349, 4249-004 Porto, Portugal; diogovidal@ufp.edu.pt

4 Department of Mathematics (DM.UTAD), University of Trás-os-Montes and Alto Douro (UTAD), Quinta de Prados, 5001-801 Vila Real, Portugal; hfps@utad.pt

5 School of Human and Social Sciences (ECHS), University of Trás-os-Montes and Alto Douro (UTAD), Quinta de Prados, 5001-801 Vila Real, Portugal; angelal@utad.pt

* Correspondence: jmagano@iscet.pt (J.M.); madinis@ufp.edu.pt (M.A.P.D.)

Citation: Magano, J.; Vidal, D.G.; Sousa, H.F.P.e; Dinis, M.A.P.; Leite, Â. Validation and Psychometric Properties of the Portuguese Version of the Coronavirus Anxiety Scale (CAS) and Fear of COVID-19 Scale (FCV-19S) and Associations with Travel, Tourism and Hospitality. Int. J. Environ. Res. Public Health 2021, 18, 427. https://doi.org/10.3390/ ijerph18020427

Received: 4 December 2020 Accepted: 4 January 2021 Published: 7 January 2021

Publisher's Note: MDPI stays neutral with regard to jurisdictional clai$\mathrm{ms}$ in published maps and institutional affiliations.

Copyright: (C) 2021 by the authors. Licensee MDPI, Basel, Switzerland. This article is an open access article distributed under the terms and conditions of the Creative Commons Attribution (CC BY) license (https:// creativecommons.org/licenses/by/ $4.0 /)$.

\begin{abstract}
The aim of this study is to determine the anxiety and fear related to coronavirus disease 2019 (COVID-19) and their associations with travel, tourism and hospitality, in the Portuguese population. The Coronavirus Anxiety Scale (CAS) and Fear of COVID-19 Scale (FCV-19S) were validated for the Portuguese population and correlations with issues related to travel, tourism and hospitality were established. CAS and FCV-19S presented a good adjustment model and solid reliability and validity. Correlations between CAS and FCV-19S and the perception of the impact of COVID-19 in travel, tourism and hospitality were found. Participants considered that COVID-19 mainly affected their holidays and leisure time. However, the strongest correlation established was between total FCV-19S and emotional fear FCV-19S and the fear of attending hotel facilities. The Portuguese versions of CAS and FCV-19S are reliable psychological tools to assess anxiety and fear in relation to COVID-19 for the general population. The use of hotel facilities is the most threatening issue related to travel, tourism and hospitality. The results suggest that hotels should invest in hygiene and safety measures that allow users to regain confidence in hotel equipment.
\end{abstract}

Keywords: Coronavirus Anxiety Scale (CAS); Fear of COVID-19 Scale (FCV-19S); travel; tourism; hospitality

\section{Introduction}

The severe acute respiratory syndrome coronavirus 2 (SARS-CoV-2) is the virus causing coronavirus disease 2019 (COVID-19), the disease that was first discovered in 2019 in China [1]. As of December 28th, 2020, there were 80,879,693 people infected with this virus around the world, and 1,766,787 died from it. In Portugal, 394,573 people were infected, and 6619 died [2]. Thus, the COVID-19 pandemic is a massive global health crisis [3]. The most common symptoms at the onset of COVID-19 are fever, cough and fatigue [4], although other symptoms include headache, hemoptysis, diarrhea, dyspnea and lymphopenia [5]. Being male, elderly and having comorbidities have been significantly associated with the risk of death among COVID-19 patients [6].

As a result of the emergence of the COVID-19 outbreak, a socio-economic crisis and profound psychological distress occurred worldwide [7]. People who became infected 
with the virus developed psychological disorders associated with the general situation (isolation, loss of income, loneliness) [8] and their particular situation (fear, uncertainty, anxiety, depression and post-traumatic stress) [9]. People who did not become infected saw their family and friends get sick, some of whom even died, triggering feelings of helplessness, anxiety and fear $[10,11]$.

Anxiety and fear about COVID-19 had other implications for people's daily lives, namely, concerning travel (for work, leisure or holidays) [12,13] and hospitality [14,15]. According to Zheng, Luo and Ritchie [9], threat severity and susceptibility may cause "travel fear", leading to protection motivation and protective travel behaviors, even after the pandemic outbreak.

Some authors felt the need to develop tools to assess anxiety and fear in the face of COVID-19. Lee [16] conceived the Coronavirus Anxiety Scale (CAS), a brief mental health screener that can be used to identify cases of dysfunctional anxiety related to COVID-19. This scale has already been adapted to the Bangla [17], Korean [18], Turkish [19] and Polish [20] languages.

Additionally, Ahorsu and colleagues [10] developed the Fear of COVID-19 Scale (FCV-19S) to identify and early intervene, psychologically, in people with high values of fear of COVID-19. This scale has been validated in the Bangla [21], Greek [22], Arabic [23], Malay [24], Italian [25], Hebrew [26] and Spanish [27] languages, Spanish language in Peru [28], Spanish language in Argentina [29], Portuguese language in Brazil [30], Japanese [31] and Chinese [32] languages and in Eastern Europe [33] and India [34].

This study aims to determine the anxiety and fear related to COVID 19 and its associations with travel, tourism and hospitality, in the Portuguese population. To this end, instruments have been validated for the Portuguese population to assess anxiety and fear in relation to COVID-19. Then, the validated tools have been associated with questions related to travel, tour-ism and hospitality. It has been hypothesized that a good model of adjustment for CAS and FCV-19S would be found for the Portuguese population (H1) and it has also been hypothesized that high levels of anxiety and fear related to COVID-19 would be positively associated with a greater perception of the pandemic's impact on travel, tourism and hospitality $(\mathrm{H} 2)$.

\section{Materials and Methods}

\subsection{Procedures}

Permission was received from the original authors $[10,16]$ to validate the instruments in a Portuguese population. It was then translated from English to Portuguese using the back-translation technique [35] (Appendix A, Tables A1 and A2; Appendix B, Tables A3 and A4). After the protocol was conceived, including the sociodemographic questionnaire, issues related to travel, tourism and hospitality, CAS and FCV-19S, it was submitted to the ethics committee of the University of Trás-os-Montes and Alto Douro (UTAD), having been approved in 1 September 2020. It was released to the general population through a social network page about the study, with data being collected between 1 October and 15 November 2020. Convenience and snowball samplings were used. Consequently, the sample is not representative of the Portuguese population. All procedures performed in this study were in accordance with the ethical standards of the institutional research committee and with the 1964 Helsinki Declaration and its later amendments. Informed consent, in which the participants were familiarized with the aims of the study and in which the confidentiality and anonymity of the data were guaranteed, as well as the strategy to destroy data after being used, preceded the investigation protocol and the participants only accessed it after giving their consent.

\subsection{Instruments}

\subsubsection{Sociodemographic Questionnaire}

This questionnaire included questions related to gender (man vs. woman), age (numerical), education (no university studies vs. university studies) and employment status 
(inactive-unemployed, sick, retired, on medical leave—vs. active—students, employees, housewives).

\subsubsection{Questions Related to Travel, Tourism and Hospitality}

Seven questions were designed to assess the participants' perceptions of the impact of COVID-19 on travel, tourism and hospitality in times of the COVID-19 pandemic. The instruction ("On a scale of 0 to 100 , please indicate how much the pandemic situation caused by COVID-19 has ..." ) proceeded with the items: $1-\ldots$ "changed your leisure activities"; 2 _.. "changed your vacations"; 3 _... "prevented you from settling in a hotel"; 4- .. "prevented you from traveling by plane"; 5- ... "prevented you from traveling by train"; 6 _... "prevented you from traveling by car"; and 7— ... "made you feel fear of attending hotel facilities".

\subsubsection{Coronavirus Anxiety Scale (CAS)}

The CAS was developed with the purpose of filling a void in the mental health response to COVID-19 [16]. According to Lee [16], a brief mental health screener that could identify probable cases of dysfunctional anxiety and symptom severity associated with the coronavirus was needed. This is a five-item scale that assesses distinct physiological reactions of anxiety related to COVID-19, highly reliable as a cluster $(\alpha=0.93)$ [16].

\subsubsection{Fear of COVID-19 Scale (FCV-19S)}

According to Ahorsu and colleagues [10], FCV-19S was developed to complement the clinical efforts in preventing the spread of and treating COVID-19 cases. This is a seven-item scale, with robust psychometric properties (composite reliability $(C R)-0.88$; average variance extracted $(A V E)-0.5$; internal consistency [Cronbach's $\alpha]-0.82$; standard error of measurement (SEM) - 1.89; item separation reliability $(S R)$ from Rasch-0.99; item separation index (SI) from Rasch-11.45; person separation reliability (PSR) from Rasch-0.77; and person separation index (PSI) from Rasch-2.82), being reliable and valid in assessing fear of COVID-19 among the general population and useful in alleviating COVID-19 fears among individuals.

\subsection{Analytical Approach}

An internal replicability approach was employed by subjecting one half of the study's data to an exploratory factor analysis (EFA) and the other half to confirmatory factor analysis (CFA) to address the sampling error influences. The EFA was used to identify representative symptoms of coronavirus anxiety, while the CFA was used to test the replicability of the EFA results. The second half of the study's data was also used to perform a series of multiple group CFAs to determine if the construct of coronavirus anxiety presents differences across demographic groups. Pearson correlations between questions related to travel, tourism and hospitality and anxiety and fear towards COVID-19 were performed, as well as Spearman correlations between anxiety and fear and sociodemographic variables. Test-retest reliability was calculated using Pearson correlations to assess the CAS and FCV$19 S$ constructs' stability and precision across time. According to the guidelines suggested by Vaz et al. [36], if the $p$-value is less than 0.05 , and the Pearson correlation coefficient is above 0.7 , then researchers have evidence of test-retest reliability. Statistical analyses were calculated using Statistical Program for Social Sciences SPSS version 27.0 (IBM Corp., Armonk, NY, USA), and CFA was run using AMOS version 27.0 (IBM Corp., Armonk, NY, USA).

\section{Results}

\subsection{Sample}

Two independent samples with the same number of participants were used. As a whole, the sample consisted of 1122 participants, of whom $725(64.6 \%)$ are women, with a 
mean age of 31.91 years of age $(S D=13.76)$, with $495(44.1 \%)$ having university studies and the remaining $(n=627 ; 55.9 \%)$ without.

Concerning professional status, $932(83.1 \%)$ are active and the remaining are inactive. The EFA sample $(n=561)$ was not different from the CFA sample $(n=561)$ in relation to sociodemographic issues (chi-square tests and Student's $t$ tests), except for age $[t(1111,613)$ $=2.22 ; p=0.027 ; d=0.13$ ], being that the EFA sample was slightly older $(M=32.82$ years old; $S D=14.32)$ than the CFA sample $(M=31.00$ years old; $S D=13.12)$.

\subsubsection{Exploratory Factor Analysis (EFA) Results: Coronavirus Anxiety Scale (CAS)}

Data screening results suggested that the five items were suitable for EFA [37]: no issues relating to sample size, missing data, nonnormality, multicollinearity or singularity. The correlation matrices were factorable [Bartlett's test of sphericity $=p<0.001$; Kaiser Meyer-Olkin $(\mathrm{KMO})$ test $=0.85)$ ], being that Goretzko et al. [38] suggested the following values, in EFA: factor loading $>0.5 ; \mathrm{KMO} \geq 0.5$; Bartlett's test of sphericity to assess the statistical significance $<0.05$; percentage of variance in extraction sums of squared loadings $>50 \%$.

The five items of the CAS were subjected to an EFA with varimax rotation. The maximum likelihood factor analysis with a cut-off point of 0.40 and the Kaiser's criterion of eigenvalues greater than 1 [39] yielded a one-factor solution as the best fit for the data, accounting for $67.64 \%$ of total variance explained. The five items meet the criteria for psychometrically sound items (Table 1). Structure coefficients ranged from 0.73 to 0.89 , and communality coefficients ranged from 0.53 to 0.79 . Correlations between items ranged from 0.45 to 0.73 . These items were reliable as a single dimension $(\alpha=0.85)$. If any item was deleted, alpha's value decreased.

The test-retest agreement was analysed item by item between the first and second $(n=31)$ evaluations. The correlations between the first and the second moments were all over $r=0.70$ and the significance was always above $p=0.50$.

Table 1. CAS EFA results.

\begin{tabular}{cccccccccc}
\hline Items & Anxiety Symptom & $\boldsymbol{L D}$ & $\boldsymbol{h}^{\mathbf{2}}$ & $\boldsymbol{M}$ & $\boldsymbol{S D}$ & $\boldsymbol{S}_{\boldsymbol{k w}}$ & $\boldsymbol{K}_{\boldsymbol{r t}}$ & $\boldsymbol{M i n}$ & $\boldsymbol{M a x}$ \\
\hline Item 1 & Dizziness & 0.89 & 0.53 & 1.12 & 0.42 & 4.94 & 29.61 & 1 & 5 \\
Item 2 & Sleep Disturbances & 0.89 & 0.60 & 1.43 & 0.74 & 2.33 & 6.19 & 1 & 5 \\
Item 3 & Tonic Immobility & 0.82 & 0.67 & 1.31 & 0.62 & 2.54 & 7.14 & 1 & 5 \\
Item 4 & Appetite Loss & 0.77 & 0.79 & 1.20 & 0.54 & 4.19 & 20.76 & 1 & 5 \\
Item 5 & Abdominal Distress & 0.73 & 0.79 & 1.23 & 0.58 & 3.64 & 15.26 & 1 & 5 \\
\hline Total & CAS & & & 6.29 & 2.35 & & & &
\end{tabular}

Notes: $L D=$ structure coefficients; $h^{2}=$ extracted communality coefficients; $M=$ mean; $S D=$ standard deviation $S_{k w}=$ skewness; $K_{r t}=$ kurtosis; Min = minimum; Max = maximum; CAS = Coronavirus Anxiety Scale.

\subsubsection{Confirmatory Factor Analysis (CFA) Results: Coronavirus Anxiety Scale (CAS)}

To test the model found in EFA, a CFA was performed. The results supported the EFA findings (Figure 1). A one-factor model was found $\left[\chi^{2}(4)=7.67, p=0.11\right]$ with an excellent fit for all of the indices $\left[\chi^{2} / d f\right.$ ratio $=1.92$; Comparative Fit Index $(C F I)=1.00$; Tucker Lewis Index $(T L I)=0.99$; Standardized Root-Mean-Square Residual $(S R M R)=0.02$; RootMean-Square Error of Approximation $(R M S E A)=0.04(0.00,0.05 ; 90 \%$ Confidence Interval $(C I)$; $p$-value of Close Fit $(P C L O S E)=0.58]$. However, to achieve this model, a correlation between two items' errors (items 1 and 4) was established. To test if the coronavirus anxiety construct was measured the same way across genders (women vs. men), multigroup CFAs were performed. The results demonstrated gender differences, which were evidenced by the model fit $\left[\chi^{2}(8)=21.90, p=0.05\right]\left[\chi^{2} / d f\right.$ ratio $=2.74 ; C F I=0.99 ; T L I=0.98 ; S R M R=0.04$; RMSEA $=0.06(0.00,0.06 ; 90 \%$ CI $) ;$ PCLOSE $=0.33]$ and a significant increase in the $\chi^{2}$ value $\left[\Delta \chi^{2}(4)=27.79, p<0.001\right]$ between the models. Women $(M=1.32 ; S D=0.50)$ presented higher levels of anxiety related to COVID-19 than men $(M=1.14 ; S D=0.31)$. 


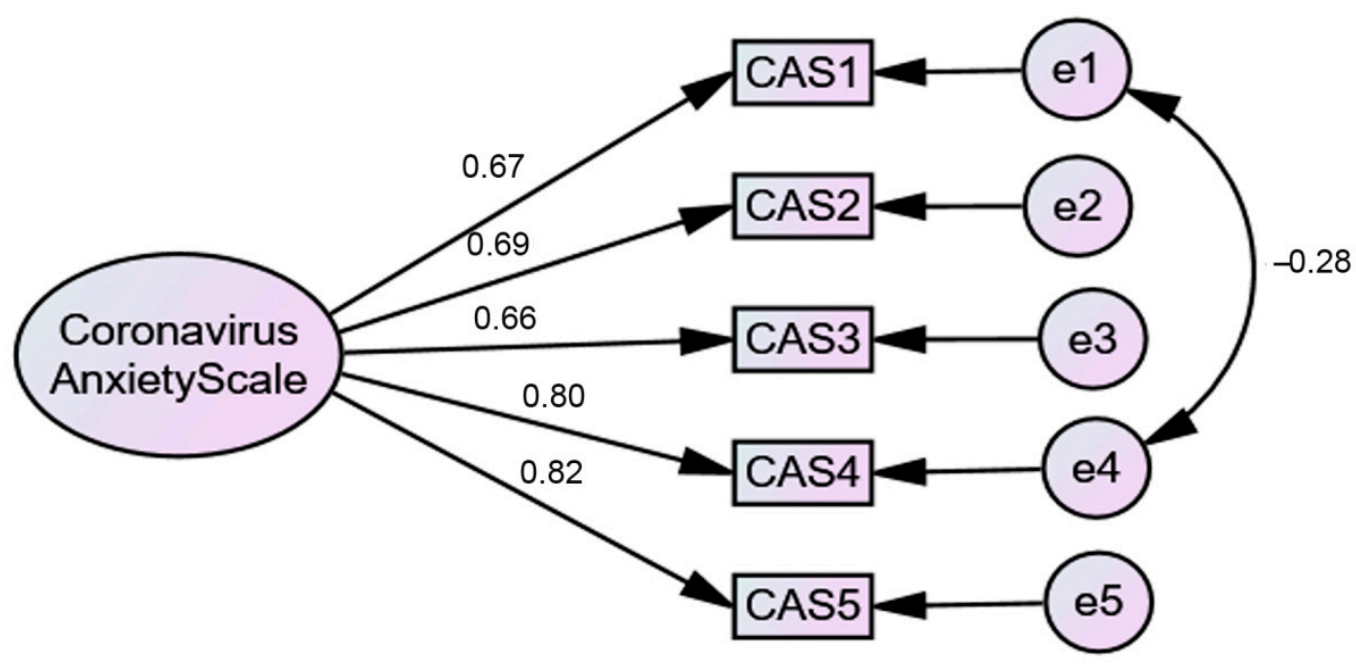

Figure 1. One-factor CFA model.

\subsubsection{Exploratory Factor Analysis (EFA) Results: Fear of COVID-19 Scale (FCV-19S)}

Data screening results suggested that the seven items were suitable for EFA [37]: again, no issues relating to sample size, missing data, nonnormality, multicollinearity or singularity. The correlation matrices were also factorable [Bartlett's test of sphericity = $p<0.001$; Kaiser Meyer-Olkin $(\mathrm{KMO})$ test $=0.85)$ ].

The seven items of FCV-19S were subjected to an EFA with varimax rotation. The maximum likelihood factor analysis with a cut-off point of 0.40 and the Kaiser's criterion of eigenvalues greater than 1 [39] yielded a two-factor solution as the best fit for the data, accounting for $70.72 \%$ of total variance explained. The seven items meet the criteria for psychometrically sound items (Table 2). Structure coefficients ranged from 0.71 to 0.86 , and communality coefficients ranged from 0.57 to 0.79 . Correlations between items ranged from 0.37 to 0.72 . These items were reliable as a single dimension $(\alpha=0.88)$ (if any item was deleted, alpha's value decreased) and as two-factor dimensions (first one $\alpha=0.83$; second one $\alpha=0.82$ ).

The test-retest agreement was analysed item by item between the first and second $(N=31)$ evaluations. The correlations between the first and the second moments were all over $r=0.70$ and the significance was always above $p=0.50$.

Table 2. FCV-19S EFA results.

\begin{tabular}{|c|c|c|c|c|c|c|c|c|c|c|}
\hline Items & Fear Items & LD1 & LD2 & $h^{2}$ & $M$ & $S D$ & $S_{k w}$ & $K_{r t}$ & Min & $\operatorname{Max}$ \\
\hline Item 1 & Fear of COVID-19 & 0.86 & & 0.76 & 3.16 & 1.10 & -0.23 & -0.53 & 1 & 5 \\
\hline Item 2 & Uncomfortable & 0.81 & & 0.71 & 3.01 & 1.07 & -0.29 & -0.56 & 1 & 5 \\
\hline Item 3 & Clammy hands & & 0.82 & 0.70 & 1.68 & 0.77 & 1.30 & 2.04 & 1 & 5 \\
\hline Item 4 & Fear of dying & 0.71 & & 0.57 & 2.65 & 1.18 & 0.20 & -0.81 & 1 & 5 \\
\hline Item 5 & News anxiety & 0.71 & & 0.67 & 2.77 & 1.11 & -0.04 & -0.77 & 1 & 5 \\
\hline Item 6 & Trouble sleeping & & 0.86 & 0.79 & 1.79 & 0.88 & 1.22 & 1.33 & 1 & 5 \\
\hline Item 7 & Tachycardia & & 0.77 & 0.75 & 2.03 & 1.08 & 0.98 & 0.23 & 1 & 5 \\
\hline Total & FCV-19S & & & & 17.20 & 5.69 & & & & \\
\hline Factor 1 & $1,2,4,5$ items & Emot & al fear & & 2.90 & 0.91 & & & & \\
\hline Factor 2 & $3,6,7$ items & $\operatorname{Cog} n$ & e fear & & 1.84 & 0.79 & & & & \\
\hline
\end{tabular}

Notes: $L D=$ structure coefficients; $h^{2}=$ extracted communality coefficients; $M=$ mean; $S D=$ standard deviation; $S_{k w}=$ skewness; $K_{r t}=$ kurtosis; Min = minimum; Max = maximum; FCV-19S = Fear of Covid-19 Scale.

\subsubsection{Confirmatory Factor Analysis (CFA) Results: Fear of COVID-19 Scale (FCV-19S)}

To test the model found in EFA, a CFA was performed. The results supported the EFA findings (Figure 2). A two-factor model was found $\left[\chi^{2}(11)=39.56, p<0.001\right]$ with a moderate fit for all of the indices $\left[\chi^{2} / d f\right.$ ratio $=3.58 ; C F I=0.99 ; T L I=0.97 ; S R M R=0.03$; 
RMSEA $=0.07(0.00,0.05 ; 90 \%$ CI $) ;$ PCLOSE $=0.09]$. However, to achieve this model, a correlation between two items' errors (items 2 and 4 ) of the first factor and a correlation between two items' errors of the second factor (items 3 and 6) were established. As the items whose errors were correlated belonged to the same factor, in theory, the correlation is justified. To test if the fear of COVID-19 construct was measured the same way across genders (women vs. men), multigroup CFAs were performed. The results demonstrated gender differences, which were evidenced by the model fit $\left[\chi^{2}(22)=44.11, p=0.03\right]\left[\chi^{2} / d f\right.$ ratio $=2.01 ; C F I=0.99 ; T L I=0.98 ; S R M R=0.04 ; R M S E A=0.04(0.00,0.06 ; 90 \% C I)$; $P C L O S E=0.74]$, although the increase in the $\chi^{2}$ value $\left[\Delta \chi^{2}(5)=7.93, p<0.16\right]$ between the models was not significant. Women $(M=2.66 ; S D=0.83)$ presented higher levels of fear of COVID-19 than men $(M=2.14 ; S D=0.79)$.

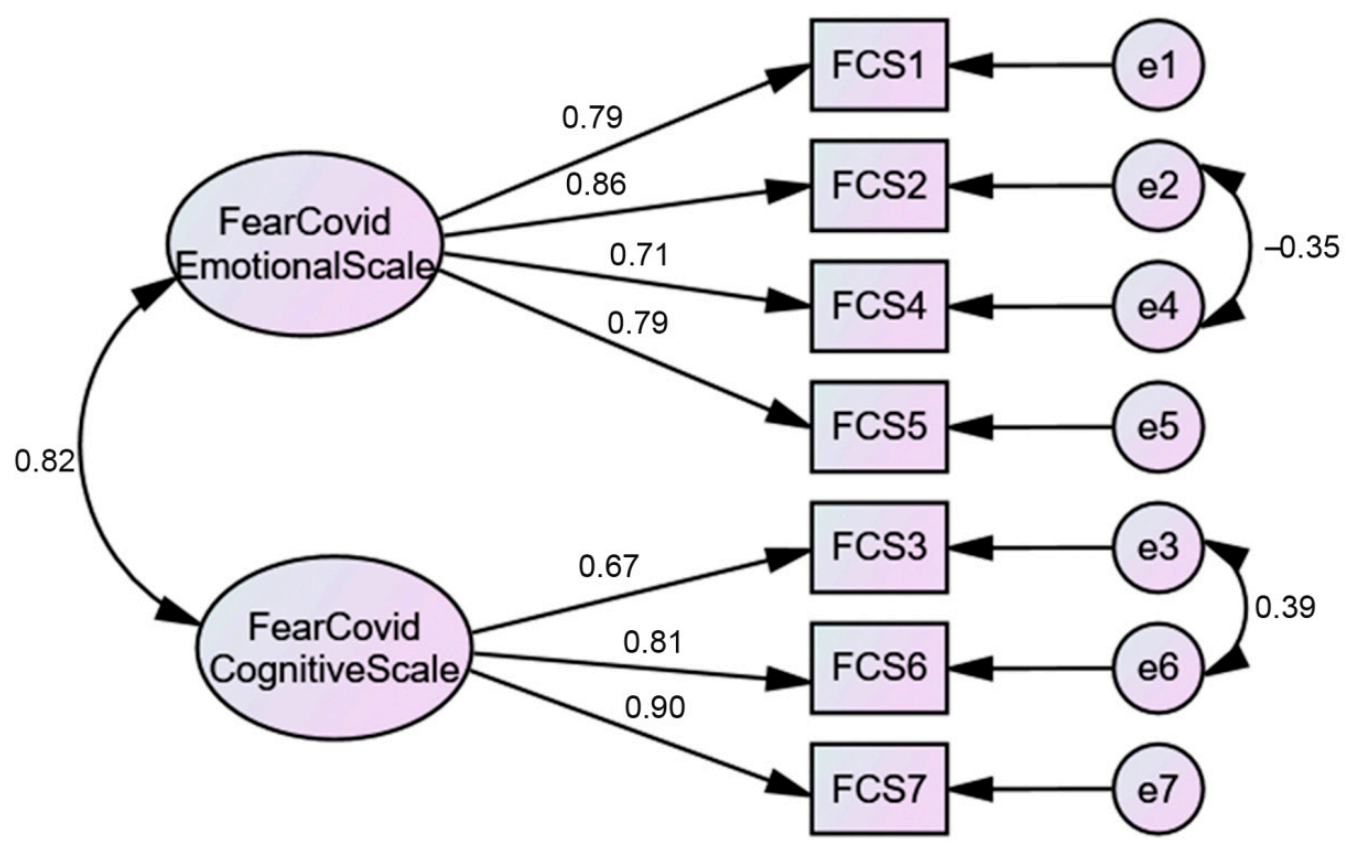

Figure 2. Two-factor CFA model.

\subsubsection{Correlations}

CAS correlates positively with FCV-19S $(r=0.53 ; p<0.001)$; with emotional fear $(r=0.43 ; p<0.001)$; and with cognitive fear $(r=0.57 ; p<0.001)$. CAS correlates positively with gender $\left(r_{\mathrm{S}}=0.15 ; p<0.001\right)$; additionally, FCV-19S correlates positively with gender $\left(r_{\mathrm{S}}=0.26 ; p<0.001\right)$, as well as emotional fear $\left(r_{\mathrm{S}}=0.29 ; p<0.001\right)$ and cognitive fear $\left(r_{\mathrm{S}}=0.18 ; p<0.001\right)$. No other correlations between CAS and FCV-19S with the selected sociodemographic variables were found.

Correlations between the seven questions about travel, tourism and hospitality range from $r=0.19$ to $r=0.63$, being all the correlations significative at the $p<0.001$ level. Cronbach's alpha suggests good reliability (Table 3). All questions concerning travel, tourism and hospitality correlate positively with the CAS and FCV-19S and their dimensions (Table 3). The highest correlations were found between FCV-19S and emotional fear, on the one hand, and attending hotel facilities, on the other hand. The correlations between the same dimensions and avoiding settling in a hotel follow. However, if paying attention to the means of the items related to travel, tourism and hospitality (Table 3), it turns out that the highest mean relates to the impact of COVID-19 on vacations and leisure time; the lowest mean refers to traveling by car. 
Table 3. Mean of COVID-related impediments and its Pearson correlations with CAS and FCV-19S.

\begin{tabular}{|c|c|c|c|c|c|c|}
\hline $\begin{array}{c}\text { Instruction: on a Scale of } 0 \text { to } 100 \text { Please } \\
\text { Indicate How Much the Pandemic Situation } \\
\text { Caused by COVID-19 .. }\end{array}$ & $M$ & $S D$ & CAS & FCV-19S & Emotional Fear & Cognitive Fear \\
\hline 1-changed your leisure activities & 71.59 & 22.49 & 0.12 & 0.27 & 0.29 & 0.19 \\
\hline 2 -changed your vacations & 72.54 & 29.79 & 0.09 & 0.19 & 0.20 & 0.12 \\
\hline 3-prevented you from settling in a hotel & 49.26 & 38.97 & 0.19 & 0.31 & 0.32 & 0.23 \\
\hline 4-prevented you from traveling by plane & 67.30 & 39.49 & 0.10 & 0.19 & 0.21 & 0.11 \\
\hline 5- prevented you from traveling by train & 47.06 & 34.83 & 0.16 & 0.25 & 0.26 & 0.19 \\
\hline 6-prevented you from traveling by car & 14.39 & 22.01 & 0.16 & 0.21 & 0.17 & 0.21 \\
\hline 7-made you feel fear of attending hotel facilities & 45.22 & 33.94 & 0.23 & 0.42 & 0.44 & 0.29 \\
\hline
\end{tabular}

Notes. $M=$ mean; $S D$ = standard deviation; CAS = Coronavirus Anxiety Scale; FCV-19S = Fear of COVID-19 Scale; all correlations are significant at the $p<0.001$ level.

\subsubsection{Regressions}

Seeking to find the variables that explained the anxiety related to COVID-19, a multiple linear regression was performed and explained $7.2 \%$ of the anxiety variance $[F(2,558)=22.57 ; p<0.001]$, being that the variables gender $(\beta=0.17 ; p<0.000)$ and use of hotel equipment $(\beta=0.20 ; p<0.000)$ contribute significantly to the explanation of this variance $\left(R^{2}=0.07\right)$. The same was performed for fear of COVID-19 and it was found that gender $(\beta=0.24 ; p<0.000)$, age $(\beta=0.07 ; p=0.050)$, leisure $(\beta=0.12 ; p<0.000)$ and use of hotel equipment $(\beta=0.37 ; p<0.000)$ contribute significantly to the explanation $\left(R^{2}=0.26\right)$ of the fear of COVID-19 variance. Considered together, these variables explain $26 \%$ of the variance of fear of having COVID-19.

\section{Discussion}

This study aims to determine the anxiety and fear associated with COVID-19 and their associations with travel, tourism and hospitality, in the Portuguese population. The study is particularly important because there were no tools to assess these constructs for the Portuguese population. Accordingly, two instruments to evaluate anxiety and fear in relation to COVID-19 were assessed and validated. CAS [16] is a five-item scale assessing distinct physiological reactions of anxiety related to the coronavirus. FCV-19S [10] is a seven-item scale assessing fear of COVID-19 among the general population. In both instruments, a high score means more anxiety and more fear, respectively. Both CFAs of the original one-factor model for CAS and the two-factor model for FCV-19S, proposed by the authors of the original scale $[10,16]$, showed a good fit with the most important indices, thus confirming the first stated hypothesis, H1. Additionally, both instruments revealed good internal consistency for the global score and the two subscales of the FCV19S. The findings are consistent with those found for CAS in a significant number of studies [16-22,24,25,27-29,31-34].

The validated tools were subsequently associated with questions related to travel, tourism and hospitality. All questions concerning travel, tourism and hospitality correlated positively with the CAS and FCV-19S and their dimensions, confirming the second hypothesis, H2, and corroborating previous studies [15,40,41]. Participants reported that the items most impacted by COVID-19 were vacations and leisure time, and the item lesser impacted was traveling by car, corroborating these results in the literature concerning leisure [42] and traveling by car [43]. In fact, leisure activities and holidays have undergone profound changes. However, although care shares have lowered in frequency, people continue to use their car alone to go to work. The strongest correlation was found between FCV-19S and emotional fear, on the one hand, and attending hotel facilities, on the other hand. Interestingly, this correlation with emotional fear suggests that, regardless of the measures that the hotel industry may be willing to carry out, emotional fear overlaps, which does not mean that the hotel industry should not continue to invest in hygiene and safety measures 
that guarantee users to regain confidence in such equipment, aiming to overcome resistance from clients.

These results are just a glimpse of how this pandemic has affected people's daily lives. All changes are generating anxiety and fear, especially when they are unwanted, as most of the changes that people have had to carry out in their life related to COVID-19 [43]. The change process alone causes anxiety. When the reason for the change causes fear, this overlap of anxiety and fear can be quite disturbing and can have lasting negative consequences. In fact, fear increases anxiety in healthy individuals and intensifies the symptoms of those with pre-existing psychiatric disorders.

\section{Conclusions}

In conclusion, this study provides the CAS and FCV-19S Portuguese versions as reliable and valid instruments, useful for measuring anxiety and fear related to COVID-19. The instruments showed good fit indices in the factor structure. The results also show good consistency indices for global scores and FCV-19S subscales. As far as it is known, these are the first instruments validated in a Portuguese population which evaluate anxiety and fear related to COVID-19. This study has some limitations. It is a cross-sectional design that hinders interpreting causality, and the questionnaire was self-applied. Future studies should test the fit of the instruments in a clinical sample.

Author Contributions: Conceptualization, J.M. and Â.L.; data curation, J.M. and Â.L.; formal analysis, J.M. and Â.L.; investigation, J.M. and Â.L.; methodology, J.M., D.G.V. and Â.L.; project administration, J.M. and Â.L.; software, J.M. and Â.L.; supervision, J.M. and Â.L.; validation, J.M., D.G.V., H.F.P.eS., M.A.P.D. and Â.L.; visualization, J.M., D.G.V., H.F.P.eS., M.A.P.D. and Â.L.; writingoriginal draft, J.M. and Â.L.; writing—review and editing, J.M., D.G.V., H.F.P.eS., M.A.P.D. and Â.L. All authors have read and agreed to the published version of the manuscript.

Funding: This research received no external funding.

Institutional Review Board Statement: The study was conducted according to the guidelines of the Declaration of Helsinki, and approved by Ethics Committee of the University of Trás-os-Montes and Alto Douro (UTAD), having been approved in 1 September 2020 (no specific reference assigned, date acting as reference ID).

Informed Consent Statement: Informed consent was obtained from all subjects involved in the study.

Data Availability Statement: The data presented in this study are available on request from the corresponding author. The data are not publicly available due to General Data Protection Regulation (GDPR).

Conflicts of Interest: The authors declare no conflict of interest.

\section{Appendix A}

Fear of COVID-19 Scale

\section{Appendix A.1. English Version}

Please indicate your level of agreement with the statements:

Table A1. Items of the Fear of COVID-19 Scale (English version).

\begin{tabular}{lccccc}
\hline \multicolumn{1}{c}{ Answers } & Strongly Disagree & Disagree & Neither Agree nor Disagree & Agree & Strongly Agree \\
\hline 1. I am most afraid of Corona. & $\square$ & $\square$ & $\square$ & $\square$ & $\square$ \\
2. It makes me uncomfortable & $\square$ & $\square$ & $\square$ & $\square$ & $\square$ \\
to think about Corona. & & & $\square$ & $\square$ & $\square$ \\
3. My hands become clammy & $\square$ & $\square$ & $\square$ & $\square$ & $\square$ \\
when I think about Corona. & $\square$ & $\square$ & $\square$ & $\square$ \\
4. I am afraid of losing my life & $\square$ & $\square$ & & $\square$ \\
\hline
\end{tabular}


Table A1. Cont.

\begin{tabular}{lccccc}
\hline \multicolumn{1}{c}{ Answers } & Strongly Disagree & Disagree & Neither Agree nor Disagree & Agree & Strongly Agree \\
\hline $\begin{array}{l}\text { 5. When watching news and } \\
\text { stories about Corona on social } \\
\text { media, I become nervous or }\end{array}$ & $\square$ & $\square$ & $\square$ & \\
anxious. & & & & \\
6. I cannot sleep because I'm & & & & \\
worrying about getting & $\square$ & $\square$ & $\square$ & $\square$ & $\square$ \\
$\begin{array}{l}\text { Corona. } \\
\text { 7. My heart races or palpitates }\end{array}$ & & & & \\
when I think about getting & $\square$ & $\square$ & $\square$ & $\square$ & $\square$ \\
$\quad$ Corona. & & & $\square$ & $\square$ \\
\hline
\end{tabular}

\section{Appendix A.2. Portuguese Version}

Por favor, assinale a sua concordância ou discordância em relação às seguintes afirmações:

Table A2. Items of the Fear of COVID-19 Scale (Portuguese version).

\begin{tabular}{|c|c|c|c|c|c|}
\hline Respostas & $\begin{array}{c}\text { Discordo } \\
\text { Completamente }\end{array}$ & Discordo & $\begin{array}{l}\text { Não Concordo } \\
\text { nem Discordo }\end{array}$ & Concordo & $\begin{array}{c}\text { Concordo } \\
\text { Completamente }\end{array}$ \\
\hline 1. Tenho muito medo do COVID-19. & $\square$ & $\square$ & $\square$ & $\square$ & $\square$ \\
\hline $\begin{array}{l}\text { 2. Fico desconfortável quando penso } \\
\text { no COVID-19. }\end{array}$ & $\square$ & $\square$ & $\square$ & $\square$ & $\square$ \\
\hline $\begin{array}{l}\text { 3. As minhas mãos ficam húmidas } \\
\text { quando penso no COVID- } 19 \text {. }\end{array}$ & $\square$ & $\square$ & $\square$ & $\square$ & $\square$ \\
\hline $\begin{array}{l}\text { 4. Tenho medo de perder a vida por } \\
\text { causa do COVID-19. }\end{array}$ & $\square$ & $\square$ & $\square$ & $\square$ & $\square$ \\
\hline $\begin{array}{l}\text { 5. Ao assistir às notícias e histórias } \\
\text { sobre o COVID-19 nas redes sociais, } \\
\text { fico nervoso(a) ou ansioso(a). }\end{array}$ & $\square$ & $\square$ & $\square$ & $\square$ & $\square$ \\
\hline $\begin{array}{l}\text { 6. Não consigo dormir porque estou } \\
\text { preocupado com a possibilidade de } \\
\text { ficar infetado(a) com COVID-19. }\end{array}$ & $\square$ & $\square$ & $\square$ & $\square$ & $\square$ \\
\hline $\begin{array}{l}\text { 7. O meu coração dispara ou palpita } \\
\text { quando penso na possibilidade de } \\
\text { ficar infetado(a) com o COVID-19. }\end{array}$ & $\square$ & $\square$ & $\square$ & $\square$ & $\square$ \\
\hline
\end{tabular}

\section{Appendix B}

Coronavirus Anxiety Scale

Appendix B.1. English Version

How often have you experienced the following activities over the last 2 weeks?

Table A3. Items of the Coronavirus Anxiety Scale (English version).

\begin{tabular}{lcccc}
\hline \multicolumn{1}{c}{ Answers } & Not at All $\begin{array}{c}\text { Rare, Less Than } \\
\text { a Day or Two }\end{array}$ & Several Days & $\begin{array}{c}\text { More Than } \\
7 \text { Days }\end{array}$ & $\begin{array}{l}\text { Nearly Every } \\
\text { Day over the } \\
\text { Last 2 Weeks }\end{array}$ \\
\hline $\begin{array}{l}\text { 1. I felt dizzy, lightheaded, or faint, when I } \\
\text { read or listened to news about the } \\
\text { coronavirus. }\end{array}$ & $\square$ & $\square$ & $\square$ & $\square$ \\
$\begin{array}{l}\text { 2. I had trouble falling or staying asleep } \\
\text { because I was thinking about the coronavirus. }\end{array}$ & $\square$ & $\square$ & $\square$ & $\square$ \\
$\begin{array}{l}\text { 3. I felt paralyzed or frozen when I thought } \\
\text { about or was exposed to information about } \\
\text { the coronavirus. }\end{array}$ & $\square$ & $\square$ & $\square$ & $\square$ \\
\hline
\end{tabular}


Table A3. Cont.

\begin{tabular}{lcccc}
\hline \multicolumn{1}{c}{ Answers } & Not at All $\begin{array}{c}\text { Rare, Less Than } \\
\text { a Day or Two }\end{array}$ & Several Days & $\begin{array}{c}\text { More Than } \\
\text { 7 Days }\end{array}$ & $\begin{array}{l}\text { Nearly Every } \\
\text { Day over the } \\
\text { Last 2 Weeks }\end{array}$ \\
\hline $\begin{array}{l}\text { 4. I lost interest in eating when I thought } \\
\text { about or was exposed to information about } \\
\text { the coronavirus. }\end{array}$ & $\square$ & $\square$ & $\square$ & $\square$ \\
$\begin{array}{l}\text { 5. I felt nauseous or had stomach problems } \\
\text { when I thought about or was exposed to } \\
\text { information about the coronavirus. }\end{array}$ & $\square$ & $\square$ & $\square$ & $\square$ \\
\hline
\end{tabular}

\section{Appendix B.2. Portuguese Version}

Tendo passado mais de uma hora (no total) por semana a pensar no coronavirus $19 \mathrm{e}$ a ver notícias nas redes sociais e na televisão sobre ele, por favor indique em quantos dias teve os seguintes sintomas:

Table A4. Items of the Coronavirus Anxiety Scale (Portuguese version).

\begin{tabular}{lccccc}
\hline \multicolumn{1}{c}{ Respostas } & Nunca & $\begin{array}{c}\text { Raramente, } \\
\text { Menos de um } \\
\text { Dia ou Dois }\end{array}$ & Vários Dias & $\begin{array}{c}\text { Mais do } \\
\text { que 7 Dias }\end{array}$ & $\begin{array}{c}\text { Quase Todos os } \\
\text { Dias nas Últimas } \\
\text { duas Semanas }\end{array}$ \\
\hline $\begin{array}{l}\text { 1. Eu sentia-me tonto ou a desmaiar quando } \\
\text { lia ou ouvia notícias sobre a COVID-19. }\end{array}$ & $\square$ & $\square$ & $\square$ & $\square$ & $\square$ \\
$\begin{array}{l}\text { 2. Tive problemas em adormecer ou manter o } \\
\text { sono porque estava a pensar na COVID-19. }\end{array}$ & $\square$ & $\square$ & $\square$ & $\square$ & $\square$ \\
$\begin{array}{l}\text { 3. Eu senti-me paralisado(a) ou gelado(a) } \\
\text { quando pensei ou fui exposto(a) a } \\
\text { informaçôes sobre a COVID-19. } \\
\begin{array}{l}\text { 4. Perdi o interesse em comer quando pensei } \\
\text { ou fui exposto a informações sobre a } \\
\text { COVID-19. }\end{array}\end{array} \quad \square$ & $\square$ & $\square$ & $\square$ & $\square$ & $\square$ \\
$\begin{array}{l}\text { 5. Senti náuseas ou problemas de estômago } \\
\text { quando pensei ou fui exposto a informaçóes } \\
\text { sobre a COVID-19. }\end{array}$ & $\square$ & $\square$ & $\square$ & $\square$ & $\square$ \\
\hline
\end{tabular}

\section{References}

1. Andersen, K.G.; Rambaut, A.; Lipkin, W.I.; Holmes, E.C.; Garry, R.F. The Proximal Origin of SARS-CoV-2. Nat. Med. 2020, 26, 450-452. [CrossRef] [PubMed]

2. Dong, E.; Du, H.; Gardner, L. An interactive web-based dashboard to track COVID-19 in real time. Lancet Infect. Dis. 2020, 20, 533-534. [CrossRef]

3. Van Bavel, J.J.; Baicker, K.; Boggio, P.S.; Capraro, V.; Cichocka, A.; Cikara, M.; Crockett, M.J.; Crum, A.J.; Douglas, K.M.; Druckman, J.N.; et al. Using social and behavioural science to support COVID-19 pandemic response. Nat. Hum. Behav. 2020, 4, 460-471. [CrossRef] [PubMed]

4. Huang, C.; Wang, Y.; Li, X.; Ren, L.; Zhao, J.; Hu, Y.; Zhang, L.; Fan, G.; Xu, J.; Gu, X.; et al. Clinical features of patients infected with 2019 novel coronavirus in Wuhan, China. Lancet 2020, 395, 497-506. [CrossRef]

5. Wang, L.; Wang, Y.; Ye, D.; Liu, Q. Review of the 2019 novel coronavirus (SARS-CoV-2) based on current evidence. Int. J. Antimicrob. Agents 2020, 55, 105948. [CrossRef] [PubMed]

6. Nikpouraghdam, M.; Jalali Farahani, A.; Alishiri, G.; Heydari, S.; Ebrahimnia, M.; Samadinia, H.; Sepandi, M.; Jafari, N.J.; Izadi, M.; Qazvini, A.; et al. Epidemiological characteristics of coronavirus disease 2019 (COVID-19) patients in IRAN: A single center study. J. Clin. Virol. 2020, 127, 104378. [CrossRef]

7. Serafini, G.; Parmigiani, B.; Amerio, A.; Aguglia, A.; Sher, L.; Amore, M. The psychological impact of COVID-19 on the mental health in the general population. QJM An Int. J. Med. 2020, 113, 531-537. [CrossRef]

8. Luchetti, M.; Lee, J.H.; Aschwanden, D.; Sesker, A.; Strickhouser, J.E.; Terracciano, A.; Sutin, A.R. The trajectory of loneliness in response to COVID-19. Am. Psychol. 2020, 75, 897-908. [CrossRef] 
9. Guo, Q.; Zheng, Y.; Shi, J.; Wang, J.; Li, G.; Li, C.; Fromson, J.A.; Xu, Y.; Liu, X.; Xu, H.; et al. Immediate psychological distress in quarantined patients with COVID-19 and its association with peripheral inflammation: A mixed-method study. Brain. Behav. Immun. 2020, 88, 17-27. [CrossRef]

10. Ahorsu, D.K.; Lin, C.-Y.; Imani, V.; Saffari, M.; Griffiths, M.D.; Pakpour, A.H. The Fear of COVID-19 Scale: Development and Initial Validation. Int. J. Ment. Health Addict. 2020. [CrossRef]

11. Hacimusalar, Y.; Kahve, A.C.; Yasar, A.B.; Aydin, M.S. Anxiety and hopelessness levels in COVID-19 pandemic: A comparative study of healthcare professionals and other community sample in Turkey. J. Psychiatr. Res. 2020, 129, 181-188. [CrossRef] [PubMed]

12. Beck, M.J.; Hensher, D.A. Insights into the impact of COVID-19 on household travel and activities in Australia-The early days under restrictions. Transp. Policy 2020, 96, 76-93. [CrossRef]

13. Jun, W.; Metin, K.; Shaohua, Y.; Fang, L. COVID-19: Potential effects on Chinese citizens' lifestyle and travel. Tour. Rev. 2020. [CrossRef]

14. American Hotel \& Lodging Association (AHLA). Leisure and Hospitality Industry Proves Hardest Hit by COVID-19. Available online: https: / www.ahla.com/covid-19s-impact-hotel-industry (accessed on 3 December 2020).

15. Nicola, M.; Alsafi, Z.; Sohrabi, C.; Kerwan, A.; Al-Jabir, A.; Iosifidis, C.; Agha, M.; Agha, R. The socio-economic implications of the coronavirus pandemic (COVID-19): A review. Int. J. Surg. 2020, 78, 185-193. [CrossRef]

16. Lee, S.A. Coronavirus Anxiety Scale: A brief mental health screener for COVID-19 related anxiety. Death Stud. 2020, 44, 393-401. [CrossRef]

17. Ahmed, O.; Faisal, R.A.; Sharker, T.; Lee, S.A.; Jobe, M.C. Adaptation of the Bangla Version of the COVID-19 Anxiety Scale. Int. J. Ment. Health Addict. 2020, 1-12. [CrossRef]

18. Choi, E.; Lee, J.; Lee, S.A. Validation of the Korean version of the obsession with COVID-19 scale and the Coronavirus anxiety scale. Death Stud. 2020, 1-7. [CrossRef]

19. Evren, C.; Evren, B.; Dalbudak, E.; Topcu, M.; Kutlu, N. Measuring anxiety related to COVID-19: A Turkish validation study of the Coronavirus Anxiety Scale. Death Stud. 2020, 1-7. [CrossRef]

20. Skalski, S.; Uram, P.; Dobrakowski, P.; Kwiatkowska, A. The link between ego-resiliency, social support, SARS-CoV-2 anxiety and trauma effects. Polish adaptation of the Coronavirus Anxiety Scale. Pers. Individ. Dif. 2020, 110540. [CrossRef]

21. Sakib, N.; Bhuiyan, A.K.M.I.; Hossain, S.; Al Mamun, F.; Hosen, I.; Abdullah, A.H.; Sarker, M.A.; Mohiuddin, M.S.; Rayhan, I.; Hossain, M.; et al. Psychometric Validation of the Bangla Fear of COVID-19 Scale: Confirmatory Factor Analysis and Rasch Analysis. Int. J. Ment. Health Addict. 2020. [CrossRef]

22. Nikopoulou, V.A.; Holeva, V.; Parlapani, E.; Karamouzi, P.; Voitsidis, P.; Porfyri, G.N.; Blekas, A.; Papigkioti, K.; Patsiala, S.; Diakogiannis, I. Mental Health Screening for COVID-19: A Proposed Cutoff Score for the Greek Version of the Fear of COVID-19 Scale (FCV-19S). Int. J. Ment. Health Addict. 2020. [CrossRef] [PubMed]

23. Alyami, M.; Henning, M.; Krägeloh, C.U.; Alyami, H. Psychometric Evaluation of the Arabic Version of the Fear of COVID-19 Scale. Int. J. Ment. Health Addict. 2020. [CrossRef]

24. Pang, N.T.P.; Kamu, A.; Hambali, N.L.B.; Mun, H.C.; Kassim, M.A.; Mohamed, N.H.; Ayu, F.; Rahim, S.S.S.A.; Omar, A.; Jeffree, M.S. Malay Version of the Fear of COVID-19 Scale: Validity and Reliability. Int. J. Ment. Health Addict. 2020. [CrossRef]

25. Soraci, P.; Ferrari, A.; Abbiati, F.A.; Del Fante, E.; De Pace, R.; Urso, A.; Griffiths, M.D. Validation and Psychometric Evaluation of the Italian Version of the Fear of COVID-19 Scale. Int. J. Ment. Health Addict. 2020. [CrossRef] [PubMed]

26. Tzur Bitan, D.; Grossman-Giron, A.; Bloch, Y.; Mayer, Y.; Shiffman, N.; Mendlovic, S. Fear of COVID-19 scale: Psychometric characteristics, reliability and validity in the Israeli population. Psychiatry Res. 2020, 289, 113100. [CrossRef] [PubMed]

27. Martínez-Lorca, M.; Martínez-Lorca, A.; Criado-Álvarez, J.J.; Armesilla, M.D.C.; Latorre, J.M. The fear of COVID-19 scale: Validation in spanish university students. Psychiatry Res. 2020, 293, 113350. [CrossRef]

28. Huarcaya-Victoria, J.; Villarreal-Zegarra, D.; Podestà, A.; Luna-Cuadros, M.A. Psychometric Properties of a Spanish Version of the Fear of COVID-19 Scale in General Population of Lima, Peru. Int. J. Ment. Health Addict. 2020. [CrossRef]

29. Caycho-Rodríguez, T.; Vilca, L.W.; Cervigni, M.; Gallegos, M.; Martino, P.; Portillo, N.; Barés, I.; Calandra, M.; Burgos Videla, C. Fear of COVID-19 scale: Validity, reliability and factorial invariance in Argentina's general population. Death Stud. 2020, 1-10. [CrossRef]

30. Cavalheiro, F.R.S.; Sticca, M.G. Adaptation and Validation of the Brazilian Version of the Fear of COVID-19 Scale. Int. J. Ment. Health Addict. 2020. [CrossRef]

31. Wakashima, K.; Asai, K.; Kobayashi, D.; Koiwa, K.; Kamoshida, S.; Sakuraba, M. The Japanese version of the Fear of COVID-19 scale: Reliability, validity, and relation to coping behavior. PLoS ONE 2020, 15, e0241958. [CrossRef]

32. Chi, X.; Chen, S.; Chen, Y.; Chen, D.; Yu, Q.; Guo, T.; Cao, Q.; Zheng, X.; Huang, S.; Hossain, M.M.; et al. Psychometric Evaluation of The Fear of COVID-19 Scale Among Chinese Population. PsyArXiv 2020. [CrossRef]

33. Reznik, A.; Gritsenko, V.; Konstantinov, V.; Khamenka, N.; Isralowitz, R. COVID-19 Fear in Eastern Europe: Validation of the Fear of COVID-19 Scale. Int. J. Ment. Health Addict. 2020, 1. [CrossRef]

34. Doshi, D.; Karunakar, P.; Sukhabogi, J.R.; Prasanna, J.S.; Mahajan, S.V. Assessing Coronavirus Fear in Indian Population Using the Fear of COVID-19 Scale. Int. J. Ment. Health Addict. 2020, 1. [CrossRef]

35. Hambleton, R.K.; Merenda, P.F.; Spielberger, C.D. Adapting Educational and Psychological Tests for Cross-Cultural Assessment; Psychology Press: East Sussex, UK, 2004. 
36. Vaz, S.; Falkmer, T.; Passmore, A.E.; Parsons, R.; Andreou, P. The case for using the repeatability coefficient when calculating test-retest reliability. PLoS ONE 2013, 8, e73990. [CrossRef]

37. Tabachnick, B.G.; Fidell, L.S. Using Multivariate Statistics, 6th ed.; Pearson: London, UK, 2013.

38. Goretzko, D.; Pham, T.T.H.; Bühner, M. Exploratory factor analysis: Current use, methodological developments and recommendations for good practice. Curr. Psychol. 2019, 1-12. [CrossRef]

39. Field, A.P. Discovering Statistics Using SPSS: (And Sex and Drugs and Rock'n'roll); Sage: Thousand Oaks, CA, USA, 2009.

40. Hoque, A.; Shikha, F.A.; Hasanat, M.W.; Arif, I.; Hamid, A.B.A. The Effect of Coronavirus ( COVID-19) in the Tourism Industry in China. Asian J. Multidiscip. Stud. 2020, 3, 52-58.

41. Zheng, D.; Luo, Q.; Ritchie, B.W. Afraid to travel after COVID-19? Self-protection, coping and resilience against pandemic 'travel fear'. Tour. Manag. 2021, 83, 104261. [CrossRef]

42. Smirni, P.; Lavanco, G.; Smirni, D. Anxiety in Older Adolescents at the Time of COVID-19. J. Clin. Med. 2020, 9, 3064. [CrossRef]

43. Singh, V.; Tech, M.; Gupta, K.; Chakrabarty, N. Psychological Impacts on the Travel Behavior Post-COVID-19; Indian Institute of Technology Roorkee: Uttarakhand, India, 2020. 